\title{
Comparing inhibitory effect some of probiotics and antibiotics against pathogenic bacteria isolated from injuries of military operations
}

\author{
Khatab azher muslh ${ }^{*}$, Halah Abdul khaliq awadh ${ }^{1}$, Abdulwahid B. Al-Shaibani ${ }^{2}$ \\ 1- Department of Biology, College of Science, University of Tikrit, Iraq (zaid2016khatab@gmail.com) \\ 2- Department of Biology, College of Science, Al-Farabi University College , Iraq
}

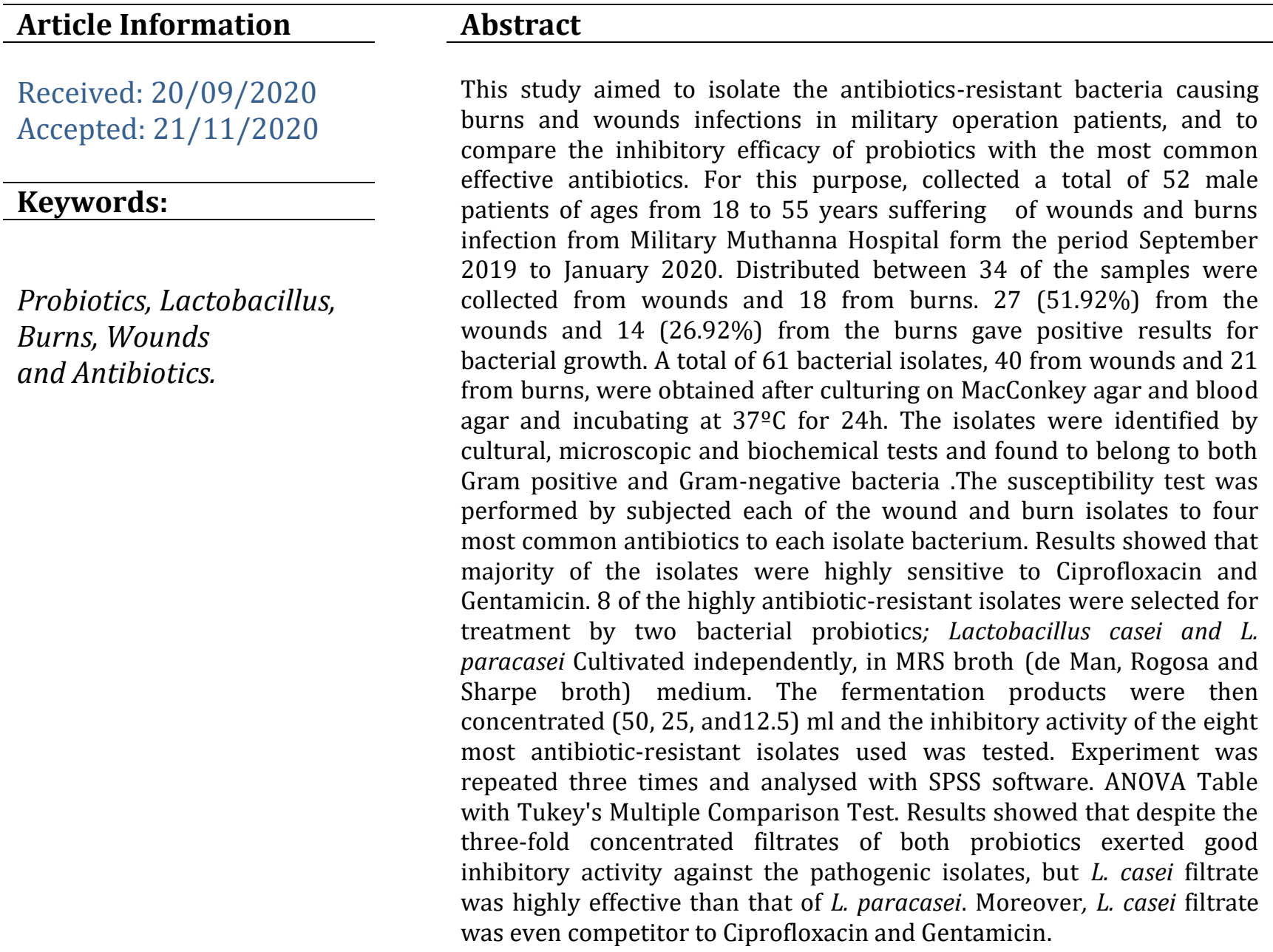

\section{Introduction:}

The skin largest organ and first barrier in the body, the skin has multiple important functions, such as preventing pathogens and dehydration, regulating body temperature, and supplying sensation. The skin is also an active immune organ, hosting cellular elements of the innate and adaptive immune systems [1]. Serious and widespread skin damage, such as burn injury, threatens the entire organism and impairs the capacity for skin regeneration. 
Moreover, with the increased prevalence of such diseases as diabetes, vascular disease, and obesity, chronic wounds are becoming a major global issue with limited treatment strategies, unsatisfactory therapeutic effects, and significant medical costs [2]. More than 200 different types of bacteria live naturally on the skin. Open wounds provide a moist, warm and ideal environment for microbial colonization and spread [3]. Urgent responding to medical needs for military operations drove for decades the pace of improvements in treating wounds, burns, infections as well as orthopaedic injuries [4]. Most specific antibiotic resistant bacterial strains are composed of Staphylococcus aureus, Klebsiella pneumoniae, Pseudomonas aeruginosa, and Acinetobacter baumannii [5].

Probiotics can restore the normal intestinal flora and prevent the growth of harmful bacteria. They may be used to compensate and reduce complications caused by antibiotics [6]. Probiotics possess many mechanisms to exert their beneficial effects such as inhibiting cell colonization adhesion, pathogen invasion having antimicrobial activity and modulate immune response of the host [7]. Moreover, Hadid [8] found among all, P. aeruginosa1 was the most affected isolate with highest recorded inhibition zone of $18 \mathrm{~mm}$. Adversely, the least effective inhibitory effect was recorded against Acinetobacter baumannii with an inhibition zone $7 \mathrm{~mm}$. Aim of this study isolate the antibiotics-resistant bacteria causing burns and wounds infections in military operation patients, and to compare the inhibitory efficacy of probiotics with the most common effective antibiotics.

New approaches and ways are needed and considered to be important in controlling wound and burn infections. Probiotics are one of the promising means in enhancing the effects of antibiotics and reducing the resistance of pathogenic bacteria to antibiotics.

\section{Materials and Methods \\ Collection and Isolation of Pathogens}

We were collected 52 sample from male patients of ages between 18 to 55 years suffering from burns and wounds infection of Military Muthanna Hospital form the period September 2019 to January 2020. Samples were taken by sterile disposable cotton swabs before returning to the transport medium. They were, then, cultured onto (MacConkey agar, Blood agar and Mannitol Salt Agar/Himedia) plates before incubating at $37^{\circ} \mathrm{C}$ for $24 \mathrm{~h}$. After incubation, identified based on colony morphology, microscopic Gram stain investigation, and standard biochemical tests [9].

\section{Antibiotic susceptibility test}

The Antibiotic susceptibility of samples was determined by disk diffusion method using (Mueller-Hinton agar/Himedia) according to the clinical and laboratory standards institute (CLSI, 2019) recommendations [10]. In the current study, the following 4 antibiotic disks

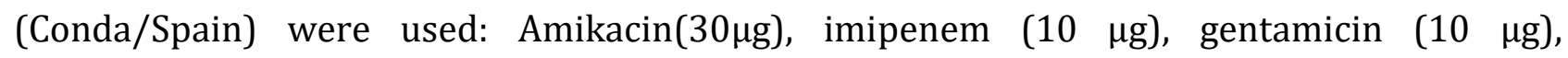
ciprofloxacin $(30 \mu \mathrm{g})$, Vancomycin $(30 \mu \mathrm{g})$ and Erythromycin $(15 \mu \mathrm{g})$.

In the bacterial suspension (0.5 McFarland) were cultured on Mueller-Hinton agar plates and then antibiotic discs were placed on the medium and incubated at $37^{\circ} \mathrm{C}$ for $16-24$ hours [11]. 


\section{Activation of probiotics}

In the current study, 2 probiotic strains were taken by the laboratories of the Department of Biotechnology / University of Baghdad. The local Lactobacillus strains included L. caesi and L. paracaesi. Probiotics were cultured in MRS broth (de Man, Rogosa and Sharpe broth/Himedia) , a selective medium for profuse growth of lactic acid bacteria, and incubated under anaerobic conditions at $37^{\circ} \mathrm{C}$ for 48 - 72 hours [12].

Then, they were transferred to MRS agar (de Man, Rogosa and Sharpe agar/Himedia) Experiment was repeated three times and analyzed with SPSS software. ANOVA Table with Tukey's Multiple Comparison Test Finally, probiotics were aseptically $-4^{\circ} \mathrm{C}$ for 2 weeks.

\section{Preparation of Probiotic Filtrates:}

A volume of $100 \mathrm{ml}$ of the fermented product (considered as unconcentrated filtrate) was concentrated to $50 \mathrm{ml}$ by putting in the Rotary evaporator at $(40-45)^{\circ} \mathrm{C}$ to make the one-fold concentrated filtrate. The experiment was repeated on the one-fold concentrated filtrate to obtain the two-fold concentrated filtrate $(25 \mathrm{ml})$, and same thing was done for the two-fold concentrated filtrate to obtain the three-fold concentrated filtrate $(12.5 \mathrm{ml})$.

\section{Determination of Probiotics Activity against Pathogenic Bacteria:}

Agar well bioassay Aslim and Kilic [13] was applied for testing the antibacterial activity of probiotics against pathogenic bacterial isolates. The probiotic bacterial isolates were prepared by inoculating $2 \%$ of the inoculum of L. casei, L. para casei $\left(6 \times 10^{8}\right)$ or the mixture of them $\left(1 \times 10^{9}\right.$ for each) in MRS broth of $\mathrm{pH} 6$. Then it was incubated anaerobically in a candle jar at $37^{\circ} \mathrm{C}$ for $48 \mathrm{~h}$ (this process was repeated three times to increase the intensity of bacterial cells). Then placed in a centrifuge at $6000 \mathrm{rpm}$ for 20 minutes, and the filter was sterilized using a Millipore filter $(0.45)$ and the precipitate was neglected.

Pathogenic bacteria cultured in Brain-heart infusion broth were prepared and activated in a Nutrient broth medium, and then incubated in aerobic conditions at $37^{\circ} \mathrm{C}$ for $24 \mathrm{~h}$. Take (0.1) $\mathrm{ml}$ of bacteria stuck at concentration $\left(1.5 * 10^{8}\right.$ bacterial cells / ml) (compared with the turbidity of the McFarland standard solution).

Then spread it on surface of Muller-Hinton with Cotton Swab in three directions with the plate rotated. At an angle of 60 in all directions, then the dishes are allowed to dry at room temperature for 15 minutes, $5 \mathrm{~mm}$ diameter wells were made by sterile cork borer in the center of Muller-Hinton agar separately cultivated pathogenic bacteria. Each well was filled with $0.1 \mathrm{~mL}$ of concentrated filter with three folds $(50,25$, and 12.5$) \mathrm{mL}$, and then incubated at $37^{\circ} \mathrm{C}$ for 24 hours. Antibacterial activity was estimated by measuring the diameters of the inhibition zone (in inches) around the well by a ruler

\section{Results and Discussion}

The 52 Samples were collected from patient males of the Military Muthanna Hospital which composed of 34 wound infections and 18 of burn infections swabs. Figure 1 shows that highest occurrence 11 cases $32.35 \%$ among wound patients was recorded in the age group of 30-40 year, while the lowest 3 cases $8.82 \%$ were in the age group of over 50 year. Regarding burn infection patients, highest occurrence 7 cases $38.8 \%$ was recorded in the $20-30$ year age 
group and the lowest1case 5.5\% was in 40-50 year age group. Results showed the most injured group with wounds and burns less than 20 and 20-30 years. The reason is due to the most age groups present on the front lines of military operations, in addition to the lack of military and security experience.

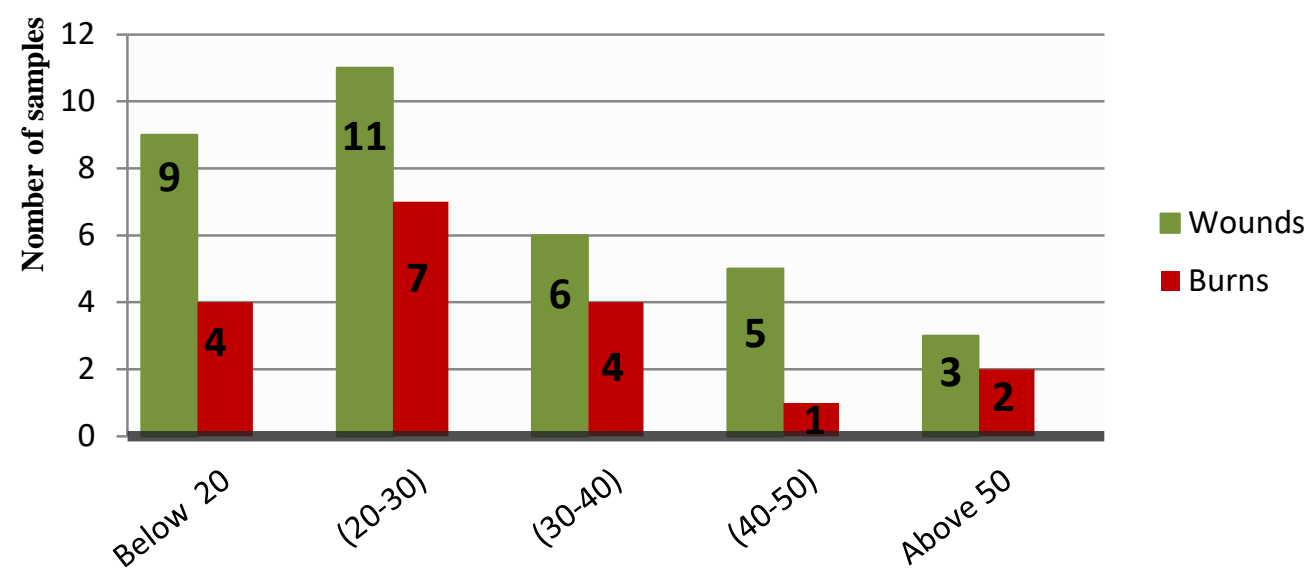

Age group (years)

Fig1: Distribution of infections according to their sources and group of patients

\section{Isolation of bacteria:}

After propagating infection samples on differential media (MacConkey agar and blood agar), 27 of the 34 wounds samples $79.41 \%$ gave positive result for the occurrence of bacterial growth, compared to $14(77.77 \%)$ of the 18 burns samples. Adversely, the rest 7 samples $(20.58 \%)$ of wounds and $4(22.22 \%)$ of burns were negative for bacterial growth. As a net result, from the total of 62 patients who suffered from wound and burn injuries, 41were found to be infected with bacterial growth while 11 patients were free of this growth.

As shown in figure 2 , Gram-positive bacteria were predominant in wound infections with 24 isolates $60 \%$ compared to 16 (40\%) isolates of Gram-negative bacteria. Adversely, Gramnegative bacteria were predominant in burn infections with 17 (80.95\%) isolates with only 4 isolates $19.04 \%$ as Gram-positive bacteria.

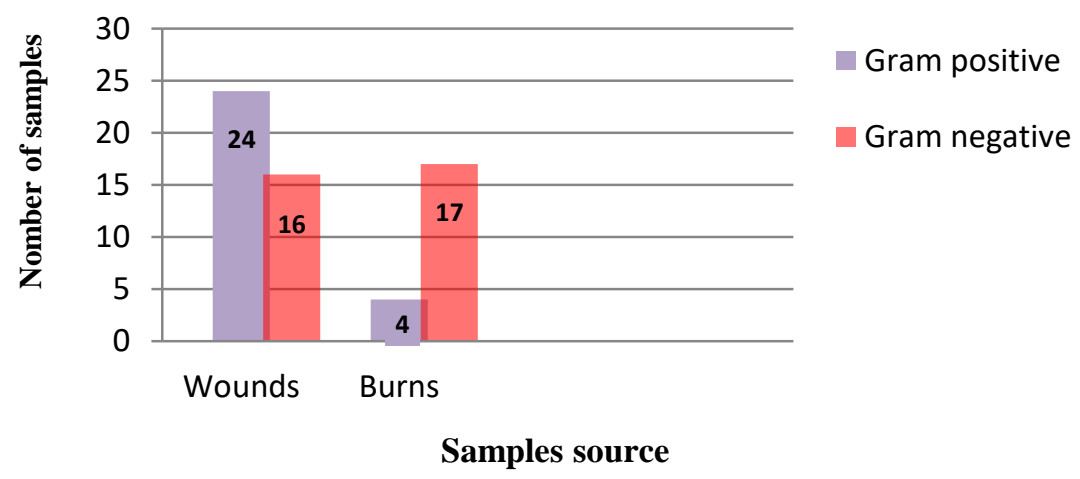

Fig 2: Distribution of wound and burn infection samples according to Gram reaction of bacteria.

Distribution of identified bacterial isolates on sources of infections 
Table 1 shows the numbers and percentages of bacterial species identified in patients suffering of wound and burn infections. Six species were detected in patient samples of wounds infection with various numbers of isolates for each. Staphylococcus aureus was the most prevalent species detected in wounds infection with a number of 18 isolates and a percentage of $45 \%$, followed by 9 isolates for Escherichia coli in a percentage of $22.5 \%$, then 6 isolates $15 \%$ for S. epidermis.

In this regard, Isibor et al., [14] found in their study that $S$. aureus was the main cause of wounds infection with a percentage of $35 \%$. A percentage of $10 \%$ was recorded by 4 isolates of Pseudomonas aeruginosa in wounds infection, which is a little lower percentage than that reported by Yeoman, and Edwards [15] who found it $16.00 \%$ and highly below than $27.8 \%$ of (year) in their studies performed also on wound infections. Adversely, Pseudomonas aeruginosa was the most dominant bacteria in samples of burn infections when it is accounted for 8 isolates (a percentage of $38.09 \%$ of the 21 isolates of this source.

This result came in accordance with the study performed in RML Delhi Hospitable by Sharma and Hans [16] who found Ps. aeruginosa as the most common bacteria in burn infections. Occurrence of Staphylococcus aureus in burn infections came in the second place with a number of 4 isolates in a percentage of $19.04 \%$.

Oncul et al.,[17] who recorded in the Teaching Hospital in Istanbul as 25\% in their studies on burn infections. Escherichia coli occurred in a percentage of $14.28 \%$ by 4 isolates. Each of Klebsiella pneumoniae and Proteus putida presented in burn infections by 3 isolates 9.5\% which came in accordance with what was found 7-10\% by Mehta et al., [18].

It could be concluded regarding occurrence of bacteria in wound and burn infections that all species listed in table 1, except Staphylococcus epidermis were detected in burn infections, while both Enterobacter cloacae and Acinetobacter baumannii were not present in wound infections.

Table 1: Bacterial species obtained from wounds and burns infections

\begin{tabular}{lcccc}
\hline \multirow{2}{*}{ Source of isolates } & \multicolumn{2}{c}{ Wounds } & \multicolumn{2}{c}{ Burns } \\
\cline { 2 - 5 } Species of bacteria & No. & $\%$ & No. & $\%$ \\
\hline Staphylococcus aureus & 18 & 45 & 4 & 19.04 \\
Escherichia coli & 9 & 22.5 & 3 & 14.28 \\
Staphylococcus epidermis & 6 & 15. & 0 & 0 \\
Pseudomonas aeruginosa & 4 & 10 & 8 & 38.09 \\
Klebsiella pneumoniae & 2 & 5 & 2 & 9.52 \\
Proteus putida & 1 & 2.5 & 2 & 9.52 \\
Enterobacter cloacae & 0 & 0 & 1 & 4.76 \\
Acinetobacter baumannii & 0 & 0 & 1 & 4.76 \\
Total & 40 & 100 & 21 & 100 \\
\hline
\end{tabular}

\section{Antibiotic susceptibility of pathogenic bacteria}


By using the disk diffusion method to test susceptibility of the bacteria isolated from wounds and burns toward six different types of antibiotics [12], the following results were obtained:

\section{Antibiotics susceptibility of wounds bacteria:}

As shown in table 2, majority of the Staphylococcus aureus 18 isolates were resistant to two of the four antibiotics used; namely Vancomycin by 13 isolates $72.22 \%$ and Erythromycin by 12 isolates $66.66 \%$. A closed result was reported by Hussain [19] who found that the percentage of Erythromycin resistance to Staphylococcus aureus was (52\%). Adversely, majority of the $18 \mathrm{~S}$. aureus isolates were sensitive to the other two antibiotics, Ciprofloxacin 13 isolates $72.22 \%$ and Gentamicin 11 isolates $61.11 \%$.

This result is close to that reported by Al-Jumaily [20] who found that $80 \%$ of the S.aureus isolates were sensitive to Ciprofloxacin. On the other hand, Rafiq [21] reported different results when found that sensitive to 100\%. Regarding Escherichia coli, majority of its 9 isolates were sensitive to all four antibiotics used; 7 (77.7\%) to Imipenem, $6(66.67 \%)$ to each of Amikacin and Gentamicin, and 5 (55.56\%) to Ciprofloxacin.

Results of a study by Desai et al., [22] showed that $23.60 \%$ of the E. coli isolates were sensitive to Ciprofloxacin and $68.55 \%$ to Gentamicin. The 6 isolates of $S$. epidermidis were sensitive to all four above antibiotics, which came in agreement with a study conducted. All 4 isolates of Pseudomonas aeruginosa were resistant to Ciprofloxacin, while 3 (75\%) of them were sensitive each of Amikacin and Gentamicin as shown in Figure 3. Hamad [23] found that $70 \%$ of isolates of this were sensitive to Gentamicin and Ciprofloxacin

Table 2: Susceptibility of bacterial isolates of wound samples toward the most common antibiotics 


\begin{tabular}{|c|c|c|c|c|c|c|c|}
\hline \multirow[b]{2}{*}{ Bacterial isolate } & \multirow[b]{2}{*}{$S \backslash R$} & \multicolumn{6}{|c|}{ Antibiotic } \\
\hline & & 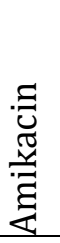 & 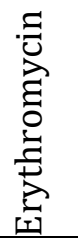 & 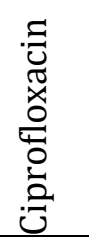 & 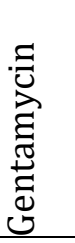 & 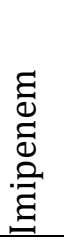 & 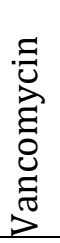 \\
\hline Staphylococcus aureus & $S$ & - & 6 & 13 & 11 & - & 5 \\
\hline$(n=18)$ & $\mathrm{R}$ & - & 12 & 5 & 7 & - & 13 \\
\hline Escherichia coli & $S$ & 6 & - & 5 & 6 & 7 & - \\
\hline$(n=9)$ & $\mathrm{R}$ & 3 & - & 4 & 3 & 2 & - \\
\hline Staphylococcus epidermis & $S$ & - & 6 & 6 & 6 & - & 6 \\
\hline$(n=6)$ & $\mathrm{R}$ & - & 0 & 0 & 0 & - & 0 \\
\hline Pseudomonas aeruginosa & $\mathrm{S}$ & 3 & - & 0 & 3 & 2 & - \\
\hline$(n=4)$ & $\mathrm{R}$ & 1 & - & 4 & 1 & 2 & - \\
\hline Klebsiella pneumoniae & $\mathrm{S}$ & 2 & - & 1 & 2 & 2 & - \\
\hline$(n=2)$ & $\mathrm{R}$ & 0 & - & 1 & 0 & 0 & - \\
\hline Proteus putida & $S$ & 1 & - & 1 & 1 & 1 & - \\
\hline$(n=1)$ & $\mathrm{R}$ & 0 & - & 0 & 0 & 0 & - \\
\hline
\end{tabular}

n: Number of isolated bacteria; S: Sensitivity; R: Resistance,: No test

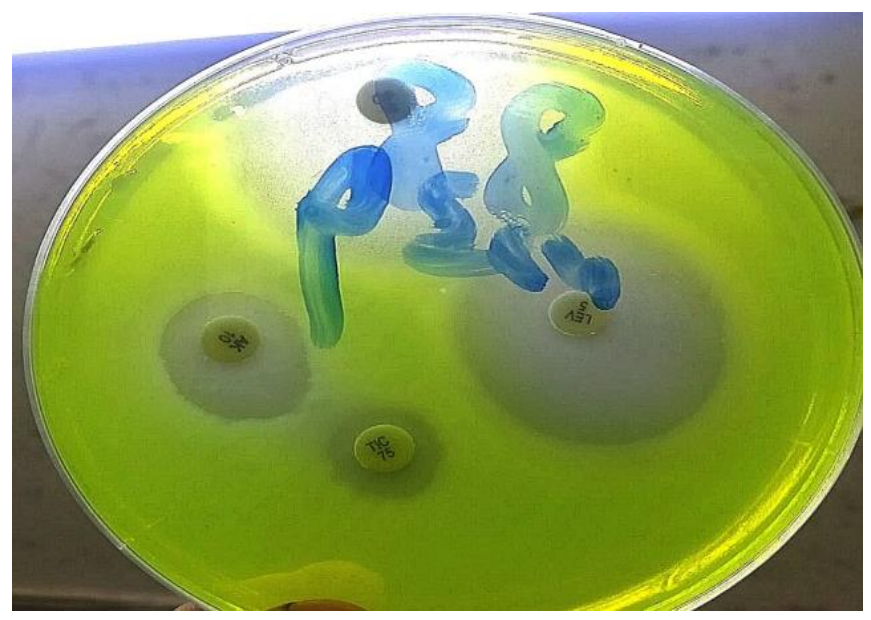

Fig 3: Inhibition zone given by Antibiotic against Pseudomonas aeruginosa isolated from burn wound infections.

\section{Antibiotics susceptibility of burns bacteria:}

As shown in table 3, highest number of isolates obtained from burn infections were belonged to Pseudomonas aeruginosa with 8 of the 21 total isolates. At the time that 6 (75\%) these bacterial isolates were resistant to antibiotic Amikacin, 6 of them were sensitivity to Imipenem. In this regard, Hamad [23] reported $70.00 \%$ resistance of $P$. aeruginosa isolates to the Amikacin. Variable susceptibility results were recorded by the 4 isolates of Staphylococcus aureus toward the antibiotics used. While all 4 (100\%) isolates were resistant to Gentamicin, 3 (75\%) were resistant to Ciprofloxacin. Davoudi et al., [24] reported that $(71.42 \%)$ of $S$. aureus isolates were resistant to Gentamycin. Two of the $3(66.66 \%)$ E. coli isolates were 
sensitive to all four antibiotics used. Moş et al., [25] reported high sensitivity of $E$. coli toward antibiotics Imipenem and Amikacin. One of the two isolates of Klebsiella pneumoniae was sensitive to all four antibiotics used while the other was resistant. The only one isolate of each of Acinetobacter baumannii and Enterobacter cloacae was sensitive to three of the four antibiotics used and resistant to only one; Imipenem and respectively. Sharmin et al., [26] found that Enterobacter spp. and Klebsiella spp. were resistant to Erythromycin 100\% For both of them. Espinal et al., [27] related sensitivity of $A$. baumannii towards antibiotics to its ability for forming biofilms which enables it to survive.

Table 3: Susceptibility of bacterial isolates of Burn samples toward the most common antibiotics

\begin{tabular}{|c|c|c|c|c|c|c|c|}
\hline \multirow[b]{2}{*}{ Bacterial Isolate } & \multirow[b]{2}{*}{$\mathrm{S} \backslash \mathrm{R}$} & \multicolumn{6}{|c|}{ Antibiotic } \\
\hline & & 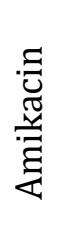 & 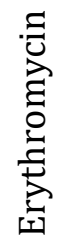 & 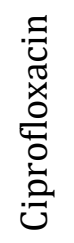 & 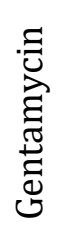 & 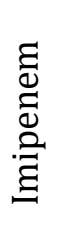 & 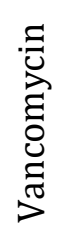 \\
\hline \multirow{4}{*}{$\begin{array}{l}\text { Pseudomonas aeruginosa } \\
(\mathrm{n}=8) \\
\text { Staphylococcus aureus } \\
(\mathrm{n}=4)\end{array}$} & $\mathrm{S}$ & 2 & - & 3 & 4 & 6 & - \\
\hline & $\mathrm{R}$ & 6 & - & 5 & 4 & 2 & - \\
\hline & S & - & 2 & 1 & 0 & - & 2 \\
\hline & $\mathrm{R}$ & - & 2 & 3 & 4 & - & 2 \\
\hline \multirow{4}{*}{$\begin{array}{l}\text { Escherichia coli } \\
(\mathrm{n}=3) \\
\text { Klebsiella pneumoniae } \\
(\mathrm{n}=2)\end{array}$} & S & 2 & - & 2 & 2 & 2 & - \\
\hline & $\mathrm{R}$ & 1 & - & 1 & 1 & 1 & - \\
\hline & S & 1 & - & 1 & 1 & 1 & - \\
\hline & $\mathrm{R}$ & 1 & - & 1 & 1 & 1 & - \\
\hline \multirow{2}{*}{$\begin{array}{l}\text { Proteus putida } \\
(\mathrm{n}=2)\end{array}$} & S & 2 & - & 0 & 1 & 2 & - \\
\hline & $\mathrm{R}$ & 0 & - & 2 & 1 & 0 & - \\
\hline \multirow{2}{*}{$\begin{array}{l}\text { Acinetobacter baumannii } \\
(\mathrm{n}=1)\end{array}$} & S & 1 & - & 1 & 1 & 0 & - \\
\hline & $\mathrm{R}$ & 0 & - & 0 & 0 & 1 & - \\
\hline \multirow{2}{*}{$\begin{array}{l}\text { Enterobacter cloacae } \\
(\mathrm{n}=1)\end{array}$} & S & 1 & 0 & 1 & - & 1 & - \\
\hline & $\mathrm{R}$ & 0 & 1 & 0 & - & 0 & - \\
\hline
\end{tabular}

$\mathrm{n}$ : Number of bacterial isolates S: Sensitive; R: Resistant; -: No test

\section{Inhibition zones of highly antibiotics-resistant isolates}

Two (BPSa39 and WPSa52) of the three P. aeruginosa isolates gave highest inhibition zones (14 and $13 \mathrm{~mm}$, respectively) against Imipenem, while the third one (BPSa21). It is not affected by inhibition; instead it gave highest inhibition zone (16 mm) against Ciprofloxacin. At the time that $S$. aureus WSa22 isolate gave inhibition zones against all four antibiotics used, its highest zone $(16 \mathrm{~mm})$ was recorded against Vancomycin. On the other hand, isolate $S$. aureus WSa56 of this species produced inhibition zones of $11 \mathrm{~mm}$ and $9 \mathrm{~mm}$ against Vancomycin and Ciprofloxacin, respectively, and no any zone against Erythromycin and Gentamycin. Regarding the two isolates of E. coli, inhibition zones of $17 \mathrm{~mm}$ and $15 \mathrm{~mm}$ were recorded by WEc111 isolate against Gentamycin and Imipenem, respectively, but no zones against each of Amikacin and Ciprofloxacin. Despite that the second isolate of E. coli BEc153 
produced no any zone against Imipenem, it gave 13, 11- and 7-mm zones against Ciprofloxacin, Gentamycin and Amikacin, respectively.

The last of the 8 isolates Klebsiella pneumoniae BKp41 produced its highest inhibition zone (11 $\mathrm{mm}$ ) against Imipenem, then Amikacin $(8 \mathrm{~mm})$, but no any zone against both Ciprofloxacin and Gentamycin. Most resistance of the pathogen to the drug used may be due to the overuse of antibiotics in treatment, which leads to greater pathogen resistance to the antibiotics [28]. Paterson [29], mentioned that taking an antibiotic much longer in how it is taken orally also affects the rate at which it is absorbed into the bloodstream.

\section{Antibacterial activity of probiotic filtrate pathogenic bacteria}

Results in tables 4 and 5 showed that the unconcentrated, one-fold and two-fold concentrated filtrates of both probiotic bacteria Lactobacillus casei, Lactobacillus paracasei had no inhibitory effect against any of the eight wounds and burns bacterial isolates. Adversely, the three-fold concentrated filtrates of both probiotics excreted seriously inhibitory activity against majority of the isolates. Generally, the three-fold filtrate of L. casei was more effective on the pathogenic isolates than L. paracasei. as shown in Figure 4.

Table 4: Inhibitory effect of unconcentrated and concentrated filtrates of probiotic bacteria Lactobacillus casei on pathogenic bacterial isolates causing wound and burn infections.

\begin{tabular}{|c|c|c|c|c|}
\hline \multirow[b]{2}{*}{ Bacterial isolate } & \multicolumn{4}{|c|}{ Inhibition zone (mm) } \\
\hline & $\begin{array}{l}\text { Unconcentrated } \\
\text { filtrate }\end{array}$ & $\begin{array}{c}\text { One-fold } \\
\text { concentrate } \\
\mathrm{d} \\
\text { filtrate }\end{array}$ & $\begin{array}{c}\text { Two-fold } \\
\text { concentrate } \\
d \\
\text { filtrate }\end{array}$ & $\begin{array}{c}\text { Three-fold } \\
\text { concentrate } \\
\mathrm{d} \\
\text { filtrate }\end{array}$ \\
\hline $\begin{array}{l}\text { P. aeruginosa } \\
\text { WPSa52 }\end{array}$ & 0 & 0 & 0 & 8.5 \\
\hline $\begin{array}{c}\text { P. aeruginosa } \\
\text { BPSa39 }\end{array}$ & 0 & 0 & 0 & 5.5 \\
\hline $\begin{array}{l}\text { P. aeruginosa } \\
\text { BPSa21 }\end{array}$ & 0 & 0 & 0 & 10.3 \\
\hline S. aureus WSa56 & 0 & 0 & 0 & 14.0 \\
\hline S. aureus WSa22 & 0 & 0 & 0 & 10.3 \\
\hline E. coli WEc111 & 0 & 0 & 0 & 11.3 \\
\hline E. coli BEc153 & 0 & 0 & 0 & 12.6 \\
\hline $\begin{array}{l}\text { K. pneumonia } \\
\text { BKp41 }\end{array}$ & 0 & 0 & 0 & 14.6 \\
\hline
\end{tabular}

W:Wound, B: Burn, N:Namber of isolate bacteria, Psa: P.aeruginosa, Sa : S.aureus, EC: E.coli, Kp : K. pneumonia.

Table 5: Inhibitory effect of unconcentrated and concentrated filtrates of probiotic bacteria Lactobacillus paracasei on pathogenic bacterial isolates causing wound and burn infections.

\begin{tabular}{l|cccc}
\hline \multirow{2}{*}{ Isolate bacteria } & \multicolumn{4}{|c}{ Inhibition zone (mm) } \\
\cline { 2 - 5 } & $\begin{array}{c}\text { Unconcentrated } \\
\text { fermentation }\end{array}$ & $\begin{array}{c}\text { One-fold) } \\
\text { Concentrated }\end{array}$ & $\begin{array}{c}\text { Two-fold) } \\
\text { Concentrated }\end{array}$ & $\begin{array}{c}\text { Three-fold } \\
\text { Concentrated }\end{array}$ \\
\hline
\end{tabular}




\begin{tabular}{llllc}
\hline $\begin{array}{l}P . \text { aeruginosa } \\
\text { WPSa52 }\end{array}$ & 0 & 0 & 0 & 6.6 \\
$\begin{array}{l}\text { P. aeruginosa } \\
\text { BPSa39 }\end{array}$ & 0 & 0 & 0 & 0 \\
$\begin{array}{l}P . \text { aeruginosa } \\
\text { BPSa21 }\end{array}$ & 0 & 0 & 0 & 10.0 \\
S. aureus WSa56 & 0 & 0 & 0 & 0 \\
S. aureus WSa22 & 0 & 0 & 0 & 0 \\
$\begin{array}{l}\text { E. coli WEc111 } \\
\text { E. coli BEc153 }\end{array}$ & 0 & 0 & 0 & 9.6 \\
K. pneumonia & 0 & 0 & 0 & 0 \\
BKp41. & 0 & 0 & 0 & 14.3 \\
\hline
\end{tabular}

W:Wound, B: Burn, , Psa: P.aeruginosa, Sa : S.aureus, EC: E.coli, Kp : K. pneumoniae, n:Namber of isolate bacteria

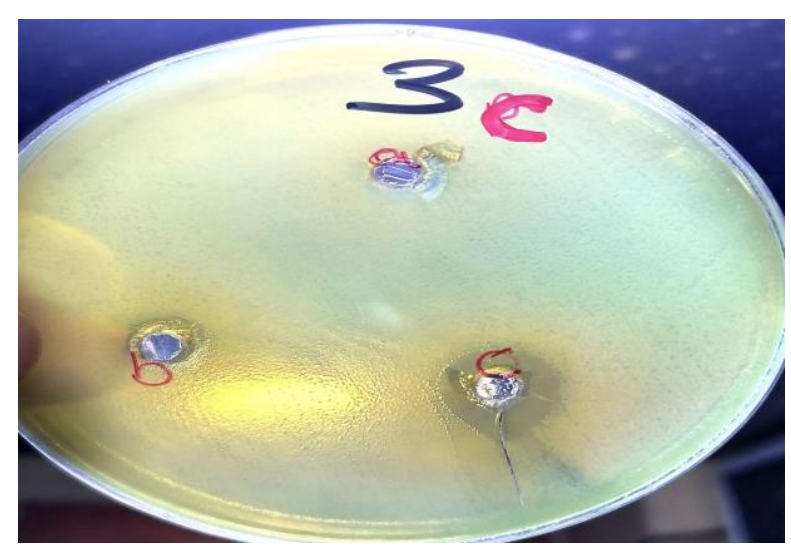

Fig 4: Inhibition zone given by Lactobacillus casei (a) one-fold concentrated fermentation product (b) Tow-fold concentrated (c) Three-fold concentrated fermentation product against (3c) S. aureus isolated from burn wound infections.

\section{Comparing antibacterial activity of probiotic filtrate and antibiotics:}

The efficacy in inhibiting growth of the antibiotics resistant bacterial isolates was compared between two the probiotics (Lactobacillus casei, L. paracasei) and two antibiotics (Gentamicin, Ciprofloxacin). Results in table 6 illustrate that $L b$. casei three-fold concentrated filtrate excreted high inhibitory effect against all bacterial isolates despite varying inhibition zone diameters, followed by antibiotics Gentamicin Ciprofloxacin.

Chuayana et al., [30] reported that most of the antimicrobial activities demonstrated by probiotics were bactericidal in nature, with the exception of $L$. casei which was antibacterial against both Staphylococcus aureus and Pseudomonas aeruginosa. This corresponds to a previous investigation which showed that the bacteria isolated from milk which identified as L. casei was bacteriostatic against Staphylococcus aureus, Pseudomonas aeruginosa sensitive to methicillin, and some other bacteria.

Dasari et al., [31] observed through the study that the areas of inhibition of probiotics are greater than those of antibiotics. When this study was conducted on P. aeruginosa, results 
showed that in about $72 \%$ of cases, areas inhibiting probiotics were greater than those of antibiotics.

Table 6: Inhibition zones formed by antibiotics (Ciprofloxacin, Gentamycin) and three-fold concentrated filtrates of probiotics (Lactobacillus casei, L. paracacsei) against wounds and burns pathogenic bacteria.

\begin{tabular}{|c|c|c|c|c|c|c|c|c|c|}
\hline \multirow[b]{2}{*}{ Isolate bacteria } & \multicolumn{9}{|c|}{ Inhibition zone (mm) } \\
\hline & $\begin{array}{l}0 \\
\tilde{5} \\
0 \\
0 \\
0\end{array}$ & $\begin{array}{l}: \\
\tilde{y} \\
0 \\
0 \\
0 \\
\vdots \\
0 \\
0 \\
\vdots \\
0\end{array}$ & 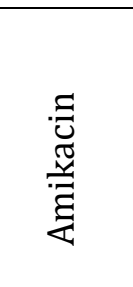 & 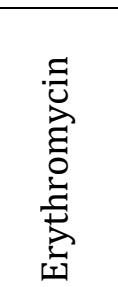 & 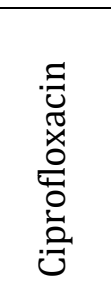 & 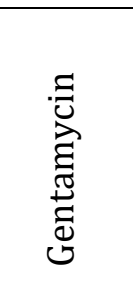 & 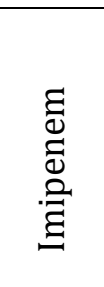 & 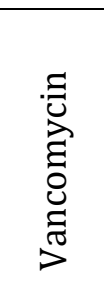 & $p$ value \\
\hline P. aeruginosa WPSa52 & 8.7 & 7.3 & 0 & - & 0 & 0 & 13 & - & $0.01^{* *}$ \\
\hline P. aeruginosa BPSa39 & 3.7 & 0.0 & 10 & - & 9 & 0 & 14 & - & $0.02^{*}$ \\
\hline P. aeruginosa BPSa21 & 10.3 & 10.0 & 9 & - & 16 & 12 & 0 & - & $0.09 \mathrm{NS}$ \\
\hline S. aureus WSa56 & 14.0 & 0.0 & - & 0 & 9 & 0 & - & 11 & $0.02 *$ \\
\hline S. aureus WSa22 & 11.0 & 0.0 & - & 11 & 14 & 10 & - & 16 & $0.17 \mathrm{NS}$ \\
\hline E. coli WEc111 & 11.3 & 9.7 & 0 & - & 0 & 17 & 15 & - & $0.14^{\mathrm{NS}}$ \\
\hline E. coli BEc153 & 12.7 & 0.0 & 7 & - & 13 & 11 & 0 & - & $0.04^{*}$ \\
\hline K. pneumonia ВКр41. & 14.7 & 14.3 & 8 & - & 0 & 0 & 11 & - & $0.08^{\mathrm{NS}}$ \\
\hline$p$ value ${ }^{\mathrm{b}}$ & - & $0.03^{*}$ & $0.14^{\mathrm{NS}}$ & $0.5^{\mathrm{NS}}$ & $0.3^{\mathrm{NS}}$ & $0.13^{\mathrm{NS}}$ & $0.7^{\mathrm{NS}}$ & $0.8^{\mathrm{NS}}$ & \\
\hline$p$ value & $0.03^{*}$ & - & $0.73^{\mathrm{NS}}$ & $0.5^{\mathrm{NS}}$ & $0.6^{\mathrm{NS}}$ & $0.7^{\mathrm{NS}}$ & $0.6^{\mathrm{NS}}$ & $0.1^{\mathrm{NS}}$ & \\
\hline
\end{tabular}

a Data presented as T test.

b Data presented as T test, antibiotic with Lb. casie.

c Data presented as T test, antibiotic with $L b$. paracasie.

NS: Non-significant. ${ }^{*}$ The correlation is significant at the $P<0.05$ level (Significant). ${ }^{* *}$ The correlation is significant at the $P<0.01$ level (Highly Significant). - no test.

\section{Conclusions}

Occurrence of wound injuries in military operations is more common than those of burns.The multibacterial pattern in wound burn infections was most common than that of monobacterial. In wound infections, Gram positive bacteria, especially Staphylococcus aureus, were the predominant pathogens, while in burn infections, Gram negative bacteria especially, Pseudomonas aeruginosa were the most common. All bacterial isolates were sensitive in different percentages to the antibiotics Ciprofloxacin and Gentamicin. As probiotics, Lactobacillus casei and L. paracasei exhibited good antibacterial activity against pathogenic bacterial isolates.

The three-fold concentrated filtrates of L. casei and L. paracasei were effective in inhibiting growth of bacterial pathogens. In fact, $L$. casei filtrate gave remarkable inhibitory effect compared to that of L. paracasei.

\section{References}

1. Ehrhardt, P., Brandner Johanna, M., \& Jens-Michael, J. (2008). The skin: an indispensable barrier. Exp Dermatol, 17, 1063-72. 
2. Sorg, H., Tilkorn, D. J., Hager, S., Hauser, J., \& Mirastschijski, U. (2017). Skin wound healing: an update on the current knowledge and concepts. European Surgical Research, 58(1-2), 81-94.

3. Young, L. (2012). Identifying infection in chronic wounds. Wound Pract. Res. J. Aust. Wound Manag. Assoc. 20, 38 .

4. Dougherty, P. J., Carter, P. R., Seligson, D., Benson, D. R. \& Purvis, J. M. (2004).Orthopaedic surgery advances resulting from World War II. JBJS 86, 176-181.

5. Murray, C. K., Roop, S. A., Hospenthal, D. R., Dooley, D. P., Wenner, K., Hammock, J., ... \& Gourdine, E. (2006). Bacteriology of war wounds at the time of injury. Military medicine, 171(9), 826-829.

6. Sharma, J. \& Chauhan, D. (2014).Inhibition of Pseudomonas aeruginosa by antibiotics and probiotics combinations-In vitro study. Eur. J. Exp. Biol. 4, 10-14.

7. Doron, S. \& Gorbach, S. L. (2006).Probiotics: their role in the treatment and prevention of disease. Expert Rev. Anti. Infect. Ther. 4, 261-275.

8. HADID, M. A. (2015).Evaluating the Effects of Probiotics and Vinegars on Bacteria Isolated from Burns and Wounds Infections.

9. James, C., \& Natalie, S. (2014). Microbiology. A laboratory manual. Pearson Education.

10. Kahlmeter, G., Giske, C. G., Kirn, T. J., \& Sharp, S. E. (2019). Point-Counterpoint: Differences between the European Committee on Antimicrobial Susceptibility Testing and Clinical and Laboratory Standards Institute Recommendations for Reporting Antimicrobial Susceptibility ResultsPoint-Counterpoint: Differences between the European Committee on Antimicrobial Susceptibility Testing and Clinical and Laboratory Standards Institute Recommendations for Reporting Antimicrobial Susceptibility ResultsPoint-Counterpoint: Differences between the European Committee on .... Journal of clinical microbiology, 57(9), e01129-19

11. Hudzicki, J. (2009). Kirby-Bauer disk diffusion susceptibility test protocol.

12. Aslim, B. and Kilic, E. (2006) 'Some probiotic properties of vaginal lactobacilli isolated from healthy women', Japanese journal of infectious diseases, 59(4), p. 249.

13. Lewus, C. B., Kaiser, A. \& Montville, T. J. (1991).Inhibition of food-borne bacterial pathogens by bacteriocins from lactic acid bacteria isolated from meat. Appl. Environ. Microbiol. 57, 1683-1688.

14. Isibor, J. O., Oseni, A., Eyaufe, A. \& Turay, A. (2008). Incidence of aerobic bacteria and Candida albicans in post-operative wound infections. African J. Microbiol. Res. 2, 288291.

15. Yeoman, K. H. \& Edwards, C. (1997).Purification and characterization of the protease enzymes of Streptomyces thermovulgaris grown in rapemeal-derived media. J. Appl. Microbiol. 82, 149-156.

16. Sharma, S. \& Hans, C. (1996).Bacterial infections in burns patients: a three years study at RML Hospital, Delhi. J. Commun. Dis. 28, 101-106.

17. Oncul, O., Yüksel, F., Altunay, H., Açikel, C., Çeliköz, B., \& Çavuşlu, Ş. (2002). The evaluation of nosocomial infection during 1-year-period in the burn unit of a training hospital in Istanbul, Turkey. Burns, 28(8), 738-744.

18. Mehta, M., Dutta, P. \& Gupta, V. (2007).Bacterial isolates from burn wound infections and their antibiograms: A eight-year study.

19. Hussain, S.S.,Obied, K.A.(2017). Study of the effect of some antibiotics on Pseudomonas aeruginosa and Staphylococcus aureus isolated from burn and wound infections. Babylon University Journal, 25 (1), 69-80.

20. Al-Jumaily, E. F., Al-obali, Y. A. J. \& Al-nasser, N. E. (2011).Extraction of caffeine from green tea plants (Camellia sinensis). J. Biotechnol. Res. Cent. 5, 9-15.

21. Rafiq, R. M. H. S. S. N. \& HAMAD, P. A. (2017). Vancomycin Resistance among Methicillin Resistant Staphylococcus aureus isolated from Clinical Samples in Erbil City, Iraq. kirkuk 
Univ. J. Sci. Stud. 12, 108-120 .

22. Desai, K. J., Malek, S. S. \& Parikh, A. (2010).Neonatal septicemia: bacterial isolates \& their antibiotics susceptibility patterns. NJIRM 1, 12-15 .

23. Hamad, L. R. (2014).Study of some plant extracts' effect on the growth of pseudomonoas aeruginosa bacteria (pathogenic and wild) and its production of pyocyanin pigment. AlAnbar J. Vet. Sci. 7, 26-32.

24. Davoudi, A., Najafi, N., Alian, S., Tayebi, A., Ahangarkani, F., Rouhi, S., \& Heydari, A. (2016). Resistance pattern of antibiotics in patient underwent open heart surgery with nosocomial infection in North of Iran. Global journal of health science, 8(2), 288.

25. Moș, I., Micle, O., Zdrâncă, M., Mureşan, M. \& Vicaş, L. (2010).Antibiotic sensitivity of the Escherichia coli strains isolated from infected skin wounds. Farmacia 58, 637-645.

26. Sharmin, S., Alamgir, F., Fahmida, M. \& Saleh, A. A. (2009).Antimicrobial sensitivity pattern of uropathogens in children. Bangladesh J. Med. Microbiol. 3, 18-22 .

27. Espinal, P., Marti, S. \& Vila, J. (2012).Effect of biofilm formation on the survival of Acinetobacter baumannii on dry surfaces. J. Hosp. Infect. 80, 56-60.

28. Rice, L. B., Willey, S. H., Papanicolaou, G. A., Medeiros, A. A., Eliopoulos, G. M., Moellering, R. C., \& Jacoby, G. A. (1990). Outbreak of ceftazidime resistance caused by extendedspectrum beta-lactamases at a Massachusetts chronic-care facility. Antimicrobial agents and chemotherapy, 34(11), 2193-2199.

29. Paterson, D. L. (2002).Looking for risk factors for the acquisition of antibiotic resistance: a 21st-century approach.

30. Chuayana, E. L., Ponce, C. V, Rivera, M. R. B. \& Cabrera, E. C. (2003) Antimicrobial activity of probiotics from milk products. Phil J. Microbiol. Infect. Dis 32, 71-74.

31. Dasari, S., Shouri, R. N. D. (2014).Wudayagiri, R. \& Valluru, L. Antimicrobial activity of Lactobacillus against microbial flora of cervicovaginal infections. Asian Pacific J. Trop. Dis. 4, 18-24. 
مقارنة الفعالية التثبيطية للمعززات الحيوية والمضادات الحيوية ضد البكتريا المرضية المعزولة من المصابين بالعمليات العسكرية

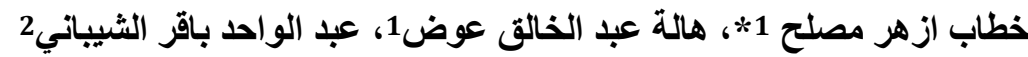

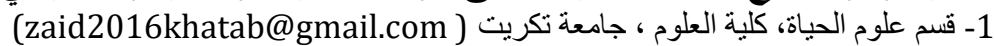

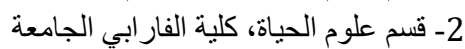
البحث مستل من رسالة دبلوم الباحث الاول البادي معلومات البحث:

هدفت هذه الدراسة إلى عزل المسبب البكتيري الذي يسبب التهابات الجروح

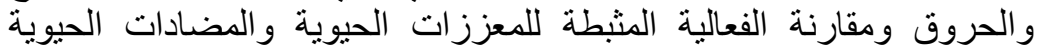

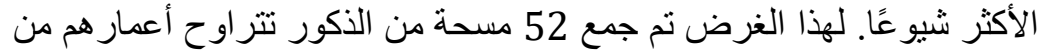

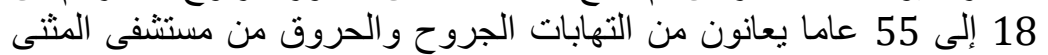

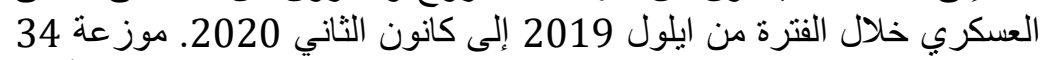

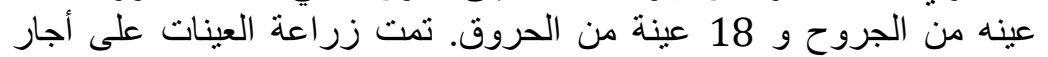

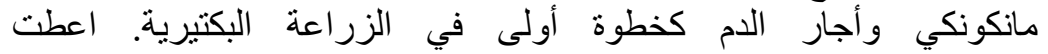

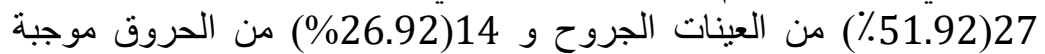

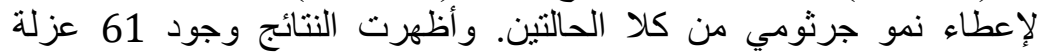

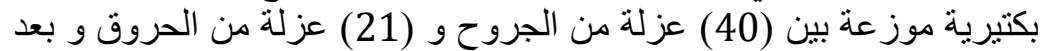

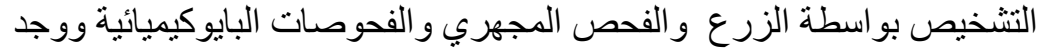

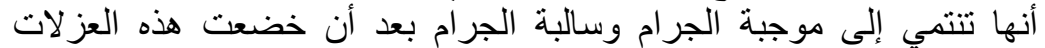

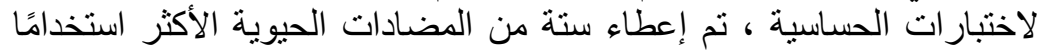

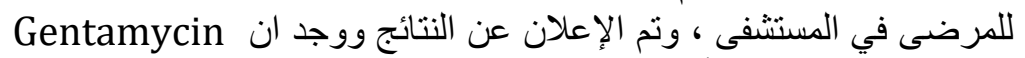

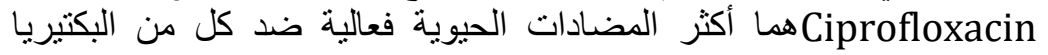

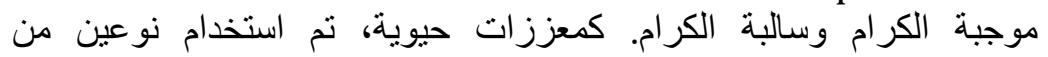
Lactobacillus casei (de Man, Rogosa and Sharpe broth مستقل، في وسط مرق MRS الفعالية المثبطة للعزلات الثمانية الأكثر مقاومة للمضادات التئر الحيوية المستخدمة.

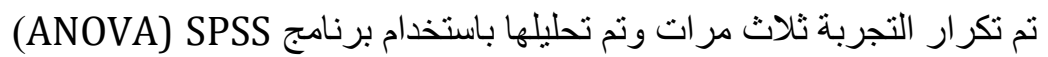

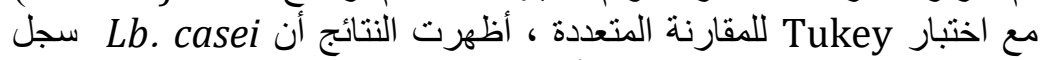

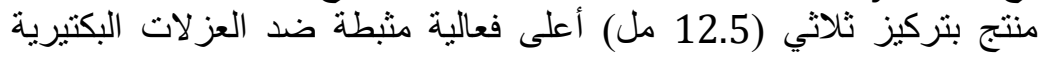

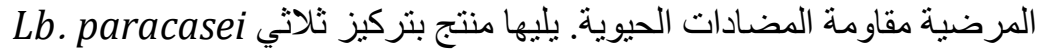

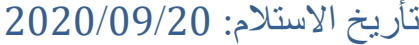

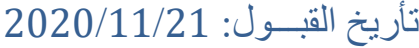

الكلمات المفتاحية:

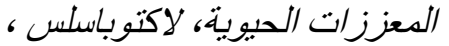
الحروق، الجروح، الدضادات الحكيانية الحيوية 